\title{
ENVIRONMENTAL EFFECTS ON THE WEIGHT OF GUZERA ANIMALS BRED
}

\author{
SOUZA, J.C. ${ }^{1}$; SILVA L.O.C. ${ }^{2}$; SANTOS, I.W. ${ }^{1}$; PIEKARSKI, P.R.B. ${ }^{1}$; \\ FERRAZ FILHO, P.B. ${ }^{3}$; VENDRUSCOLO, E.C.G. ${ }^{1}$; MALHADO, C.H.M. ${ }^{4}$; WOLF, J. ${ }^{4}$ \\ ${ }^{1}$ Departamento de Zootecnia - nelore@palotina.ufpr.br_; \\ ${ }^{2}$ Pesquisador da EMBRAPA - CNPGC, MS; \\ ${ }^{3}$ Universidade Federal de Mato Grosso do Sul; \\ ${ }^{4}$ Graduando - UFPR.
}

The whole productive chain of national livestock has being affected as a consequence of globalization. The economic market demands efficiency and speed. Beef cattle breeders are having to review their goals and to reschedule their actions to turn themselves more efficient and productive. Elevation of weaning weight and to avoid losses in the subsequent ages are conditions that allows to breeders increase the flock production. The objective of this paper is to study the influence of environment effects and the age of dam on the weaning weight (205 days) and to 365 (P365) days of age of Guzera animals. The weaning weight of 3.878 animals (P205) and 3.560 weights at (P365) were recorded. The data were from animals bred in pasture in the State of São Paulo and were provided by the Brazilian Zebu Breeders Association (ABCZ) and the National Beef Cattle Research Center which is a part of the Brazilian Agricultural Research Corporation (CNPGC/EMBRAPA). The statistical analyses were obtained using the least means square method, through the SAS (1996) program. The statistical model considered as fixed effects season (water and dry) from birth at calves (2), year from birth at calves (21), sex of calves (2) and age of dam as a covariable (linear and quadratic); as a random effect was considered a bull inside of farm (525) and the error. Results: to the weaning weight all the sources of variation in the model were significant $(P<0,01)$, except age of dam (linear). To P365 only the age of the dam was not significant $(P>0,05)$. The general average adjusted was 156.2 (2.3 for P205 and 214.4 (3,9 for P365; The season birth calves effect influenced $(P<0.0001)$ both weights, and calves borne at the dry season times were $5 \%$ heavier (159.9 vs. 152.3) for P205 and $2.4 \%$ (216.9 vs. 211.8) for P365. In relation to sex, the males weighed 162.4 (2.3 and the females 149.9 (2.3, males were $8.3 \%$ superiors in relation to females. To P365 males weighed 230.9 (3.9 and females 197,8 (3.9, a difference of $16,7 \%$ more of males in relation to females. The effect of age of dam on the weaning weight is shown in Figure 1, which the maximum age of production happened about 78.2 months. Dam with age up at 144 months tended to weaning calves below of average. Conclusion. The environmental effects influenced on weaning and early weights, evidencing that the adjustment for this effect is necessary when selecting animals. The management of birth on a dry period (that includes August and September) could increase the profitability of cattle.

KWords: cattle, Guzera race; environmental effects; weaning weight. 